\title{
Development of reduced fat cream cheese by using inulin and wpc as a fat replacer
}

\author{
Krishna K Nand Bikash C Ghosh
}

Received: 02 May 2019 / Accepted: 10 October 2019 / Published online: 31 December 2019

(C) Indian Dairy Association (India) 2019

\begin{abstract}
Cream cheese is a soft, mild, rich, creamy white, slightly acidic, unripened cheese with diacetyl flavour. The focus of the present investigation was to develop reduced fat cream cheese by using inulin and WPC as a fat replacer. Cream Cheese (control) and Reduced Fat Cream Cheese (RFCC) were prepared by fermentation of cream and skim milk separately followed by straining with muslin cloth and hanging for $12-13$ hours at $7-8^{\circ} \mathrm{C}$. Fermented mass and fermented cream was then mixed in 3:1 and 6:1 ratio to obtain control and RFCC, respectively. Inulin and WPC of 4 and $6 \%$ were incorporated in RFCC. Cheese made with $4 \%$ inulin scored significantly $(\mathrm{p}<0.05)$ higher body and texture and overall acceptability scores indicating the best resultant product. The moisture content and firmness showed inverse relationship whereas spreadability showed direct relationship with inulin incorporation. RFCC with $4 \%$ inulin showed better spreadability $(0.0167 \mathrm{~g} . \mathrm{sec})$, lowest firmness $(1.73 \mathrm{~N})$ and moisture content (75.59\%). Among 4 and $6 \%$, incorporation of $4 \%$ WPC in RFCC, showed better sensory, physico chemical and textural properties than those made with $6 \%$ WPC. Moisture and firmness showed inverse relationship while spreadability and acidity increased significantly $(\mathrm{p}<0.05)$ with increase in WPC level.
\end{abstract}

Dairy Technology Section,

ICAR-National Dairy Research Institute

Adugodi, Bengaluru - 560 030, Karnataka, India

Bikash C Ghosh $(\square)$

Dairy Technology Section,

ICAR-National Dairy Research Institute

Adugodi, Bengaluru - 560 030, Karnataka, India

Email : ghosgoga@hotmail.com; Tel: +9180 25701662;Fax : 08025710161
Cheese made with combination of 2\% inulin and 2\% WPC scored significantly $(\mathrm{p}<0.05)$ lower score than control. The spreadability of $4 \%$ inulin incorporated cheese was significantly $(p<0.05)$ higher followed by the cheese made combination of $2 \%$ inulin and $2 \%$ WPC than RFCC. Total solids and fat contents of experimental samples were significantly $(\mathrm{p}<0.05)$ lower than control cheese. Incorporation of $4 \%$ inulin in reduced fat cream cheesed was adjudged best among the incorporation of inulin, WPC and their combination.

Keywords: Cream cheese, inulin, WPC, Spreadability, Reduced fat

\section{Introduction}

Cream cheese is one of the most popular soft cheeses in North America. It is a soft, mild, rich, unripened cheese and is creamy white having slightly acidic taste with a diacetyl flavour. It is usually manufactured by the coagulation of cream or mixture of milk and cream by acidification with starter culture. It can be used as a spread on bread as a butter substitute, as a salad dressing and as an ingredient for making several kinds of desserts, such as cheesecake (Phadungath, 2005).

Fat content of cream cheese varies between $30-33 \%$. It contributes to the sensory and functional properties apart from its nutritional significance in cheese (Miocinovic et al. 2011). However, consumers are becoming increasingly aware of the relationship between diet and health and the foremost concern in this regard relates to the consumption of fat from cheese and other dairy products (Tunick et al. 1993). Fat consumption has been shown to be associated with an increased risk of obesity, atherosclerosis, coronary heart disease, elevated blood pressure and tissue injury diseases associated with lipid oxidation. This association has created an increased awareness and a dramatic increase in the demand and supply for, low-fat foods, including cheese varieties (Katsiari et al. 2002). Therefore to reduce the fat content by using fat replacer may be an alternative.

The problems associated with reducing fat content in crem cheese were an imbalance and lack of flavour have been associated with lowered levels of fatty acids (Banks et al. 1989). Furthermore, 
milk fat normally provides a typical smoothness to a full fat cheese by being evenly distributed within the casein matrix of cheese. When fat is removed, casein plays a greater role in texture development (Lawrence et al. 1987).

Fat replacers are additives used to replace all or a part of fat in a food system without significantly affecting the texture, taste and flavour (Akin et al. 2007). They are categorized as fat substitutes (fat-based) and fat mimetics (protein and carbohydrate-based). These ingredients are used to improve sensory and functional properties of low-fat cheeses by binding water and improving texture and yield (Drake et al. 1996).

Fat mimetic like inulin (carbohydrate based) and WPC (protein based) are commonly used to improve the body and texture in reduced fat dairy products. It is a food ingredient that belongs to a class of carbohydrates known as fructans. Nutritionally it has functional properties and health-promoting effects that include reduced calorie value, dietary fibre and prebiotic effects and as a fat replacer (Karimi et al. 2014). Consequently, inulin promotes the growth of healthy bacteria and enhances calcium and magnesium absorption and immune functions, and reduces the level of cholesterol and serum lipids (Rowland et al. 1998; Staffolo et al. 2004). Furthermore, the fermentation of inulin may stimulate the formation of short-chain fatty acids such as acetate, propionate and butyrate, the latter being the preferred energy substrate for colonocytes (Kruse et al. 1999).

The demand of soft fresh cheese (cream cheese) in India is increasing, especially due to its taste and flavour and as well as its use as butter substitute (Phadungath, C. (2005). The fatsubstituting property of inulin is based on its ability to stabilize the structure of the aqueous phase, which creates an improved creaminess (Ibrahim et al. 2010). A creamy mouthfeel is achieved when inulin is used as a fat replacer in dairy products due to its interactions with whey protein and caseinate. Addition of 5\% inulin to the low-fat cheese resulted in a significantly lower hardness compared to the low-fat control cheese, but slightly higher than that of the full-fat control cheese (Koca and Matin, 2004).

Whey Protein Concentrate (WPC) has been considered as an interesting fat-substitute ingredient due to its functional and technological properties, as well as its nutritional properties since it contains high concentrations of bioactive proteins (Vidigal et al. 2012). Whey protein functionality is associated with its composition and degree of denaturation (Lizarraga et al. 2006). These provided a porous, less dense and fine protein network to the cheese and close textural characteristics compared to those of full-fat cheese. Also whey proteins possess excellent emulsifying properties (Dickinson, 1997). Incorporation of WPC in production of soft cheese and low-fat cheese to maximizes the yield and improve the texture and flavour. In the production of the soft and reduced-fat cheeses, incorporation of WPC shows positive results in terms of replacing fat and increasing waterbinding ability (Jooyandeh, 2009). The objective of this study was to investigate the possibility of using inulin and WPC in the manufacture of reduced fat cream cheese, and the effect of addition on sensory, textural and physico-chemical properties of cream cheese.

\section{Materials and Methods}

Skim milk and Cream ( $40 \%$ fat) were procured from experimental dairy plant SRS of ICAR-NDRI, Bengaluru. Freeze dried lactic mesophilic DVS starter culture (Lactobcoccus lactis, Lactococcus cremoris, Lactococcus diacetylactis) from M/s. DSM was used. Inulin and WPC were procured from M/s DKSH India Pvt. Ltd. Bengaluru. Analytical grade (AR) chemicals obtained from various reputed companies were used for chemical analysis. Glassware of Borosil brand was used for the analysis of cream cheese .

\section{Preparation of Cream cheese}

Cream cheese was prepared as per the method described by Guinee et al. (1993) with slight modifications.Normally fermented whole milk is used for the preparation of cream cheese, here moisture is removed by centrifugal force. In absence of basket centrifuge drainage of whey done by using muslin cloth and hanging the curd in cold room. Skim milk and cream fermented separately to facilitate drainage of whey and easy for standardization of fat in cream cheese. Skim milk (cow milk) and cream ( $40 \%$ fat) were heated separately at $90 \mathrm{p} \mathrm{C}$ for $10 \mathrm{~min}$ and $70 \mathrm{p} \mathrm{C}$ for $20 \mathrm{~min}$, respectively. Skim milk and cream were cooled to $35 \mathrm{p} \mathrm{C}$ and inoculated with $0.03 \%$ lactic mesophilic DVS starter culture followed by incubation at $35 \mathrm{p} \mathrm{C}$ for 10-12 hours. Both fermented skim milk and cream were strained with muslin cloth and were kept hanging for 12-13 hours at 7-8p C. Fermented mass and fermented cream were then mixed at $3: 1$ and $6: 1$ ratio to obtain control and reduced fat cream cheese respectively (Figure 1). Heated and cooled inulin and WPC were mixed with reduced fat cream cheese to obtain final product. Salt was added at $0.5 \%$ $(\mathrm{w} / \mathrm{w})$ in both the cheeses and mixed well. Cheeses were packed in $150 \mathrm{ml}$ polypropylene cups and covered with lid. The products were kept in refrigerator till further analysis.

\section{Analyses \\ Sensory Evaluation}

Cheese samples were evaluated for sensory attributes viz. flavour and taste, body and texture, colour and appearance and overall acceptability by sensory panellists (minimum of 6 members) on a 9- point hedonic scale (Amerine et al. 1965). Where 9 point hedonic scale indicates 9- Like extremely, 8- Like very much, 7Like moderately, 6- Like slightly, 5- neither like nor dislike, 4dislike slightly, 3- dislike moderately, 2- dislike very much, 1dislike extremely

\section{Physico-chemical properties}




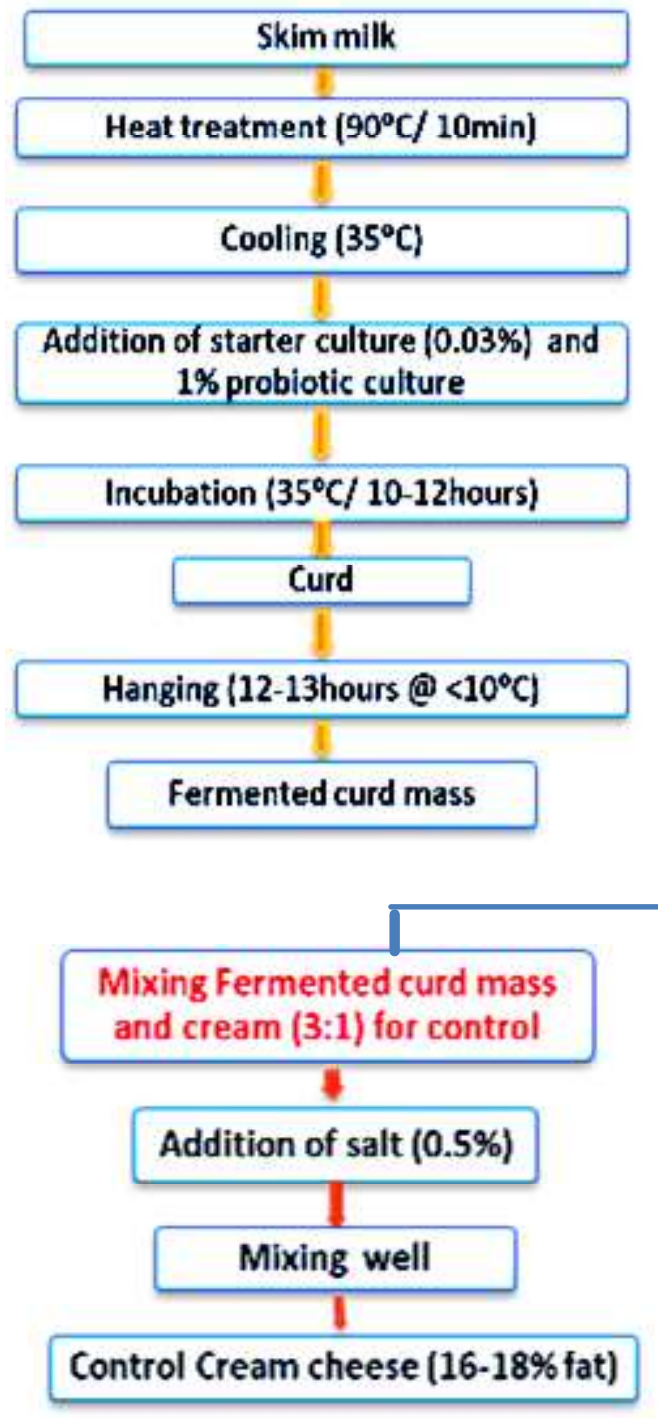

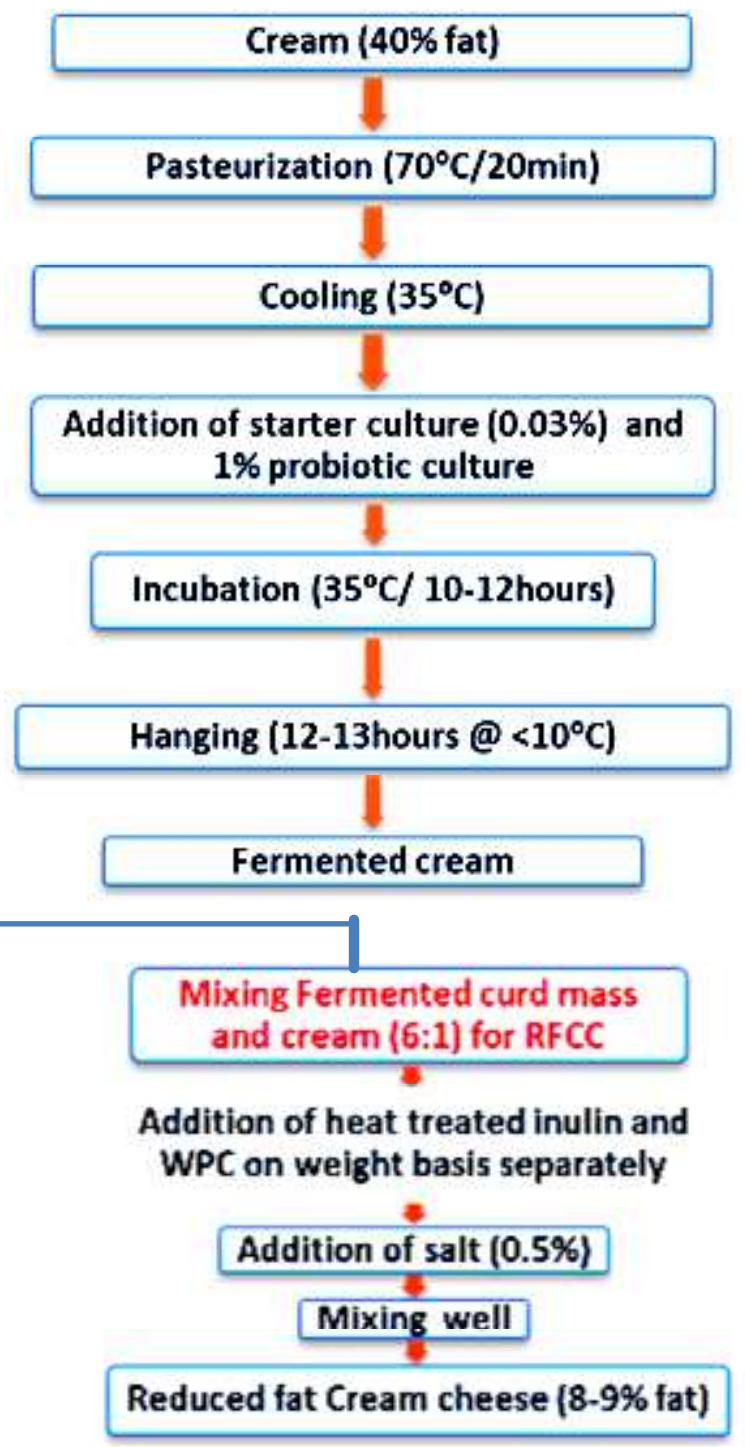

Fig. 1 Flow diagram for the preparation of Control and Reduced Fat Cream Cheese (RFCC)

Moisture content of cream cheese was estimated by gravimetric method (IS, SP: 18 Part XI, 1981). Fat, ash, protein and acidity in cream cheese were determined as described in AOAC 920.124 (2005). The $\mathrm{pH}$ of cream cheese was measured as described by Awad et al. (2005).

\section{Statistical Analysis}

Data on sensory, textural and physico-chemical analysis obtained in the study were subjected to statistical analysis by one way ANOVA using SPSS. The differences among the treatment were measured at $5 \%$ level of significance for three replications

\section{Textural analysis}

Textural properties of Cream cheese were determined using a TA.XT plus texture analyzer (Stable Micro Systems Ltd., Godalming, UK). The measurements were performed using a
Perspex spreadability rig which consisted of a set of precisely matching $60^{\circ}$. Perspex cone probe and the cone shaped sample holder. The cone sample holder was filled with about $20 \mathrm{~g}$ Cream cheese and the cone probe was allowed to penetrate into the sample@3 $3 \mathrm{mms}^{-1}$ to a depth of $18 \mathrm{~mm}$ and return back to the original position@10 $\mathrm{mms}^{-1}$ (post-test speed). During the penetration, the resistance force encountered by the probe in spreading the sample out of the cone sample holder was measured and plotted as a liner scale versus time taken by the probe. Maximum positive force on positive peak was measured as a Firmness $(\mathrm{N})$. The area of the positive peak of the plot measured as N. s and its inverse was taken as spreadability $\left(\mathrm{N}\right.$. s $\left.{ }^{-1}\right)$. Similarly, area of negative peak was recorded as Index of viscosity (g.s).The samples stored in refrigeration were tempered for $30 \mathrm{~min}$ at room temperature before performing the tests. The typical spreadability graph as obtained by the texture analyzer is as follows. 

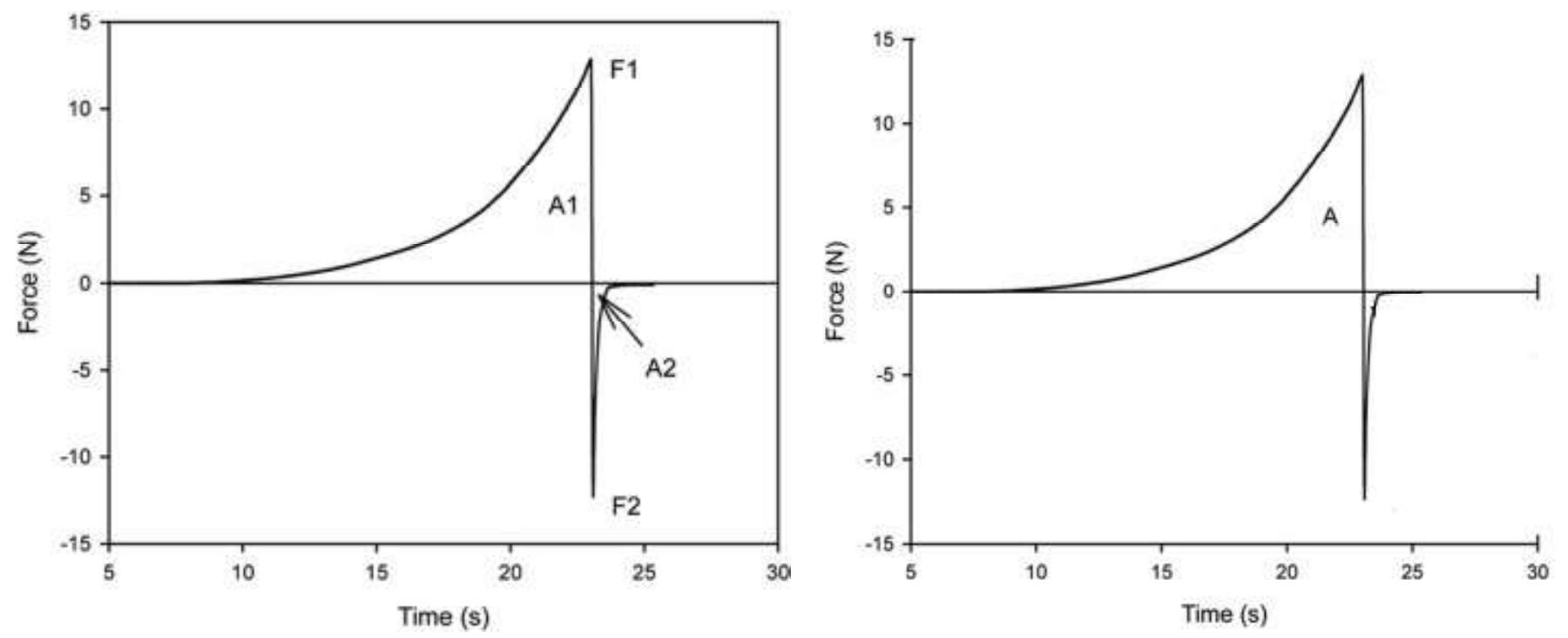

Fig. 2 Texture Analyser force - time curve indicating area of positive peak (A, N.s) (Spreadability=1/A N.s-1)

Table 1 Effect of inulin incorporation on the sensory properties of cream cheese

\begin{tabular}{lllll}
\hline Sensory attributes & Control & RFCC & \multicolumn{2}{l}{ RFCC with Inulin } \\
\cline { 4 - 5 } & & & $4 \%$ & $6 \%$ \\
\hline Flavour and taste & $7.67 \pm 0.26^{\mathrm{c}}$ & $7.09 \pm 0.35^{\mathrm{a}}$ & $7.65 \pm 0.13^{\mathrm{b}} \mathrm{c}$ & $7.44 \pm 0.42^{\mathrm{b}}$ \\
Body and Texture & $7.75 \pm 0.11^{\mathrm{b}}$ & $7.29 \pm 0.31^{\mathrm{a}}$ & $7.71 \pm 0.13^{\mathrm{b}}$ & $7.67 \pm 0.25^{\mathrm{b}}$ \\
Appearance and colour & $7.86 \pm 0.07^{\mathrm{a}}$ & $7.8 \pm 0.25^{\mathrm{a}}$ & $8.08 \pm 0.07^{\mathrm{a}}$ & $7.83 \pm 0.14^{\mathrm{a}}$ \\
Overall acceptability & $7.87 \pm 0.49^{\mathrm{b}}$ & $7.51 \pm 0.13^{\mathrm{a}}$ & $7.83 \pm 0.51^{\mathrm{b}}$ & $7.72 \pm 0.36^{\mathrm{a}}$ \\
\hline
\end{tabular}

Means with different superscript in a row differ significantly $(p<0.05)(n=3)$

\section{Results and Discussion}

\section{Optimizations of Inulin level for the preparation of reduced fat cream cheese}

The effects of 4 and $6 \%$ inulin addition on sensory, texture and physico chemical properties were studied as mentioned below.

\section{Effect on the sensory attributes}

Flavour and taste score were maximum in control followed by RFCC with 4 and $6 \%$ inulin incorporated cheese (Table 1). The flavour and taste scores of control and RFCC with $4 \%$ inulin were significantly $(\mathrm{p}<0.05)$ higher among all the cheeses. The body and texture score of reduced fat cream cheese (RFCC) without inulin showed significantly $(p<0.05)$ lower than that of inulin incorporated cheese. Inulin addition of $6 \%$ was found to increase the body \& texture score significantly $(\mathrm{p}<0.05)$ higher as compared to RFCC. Colour and appearance of the cheeses did not show any significant $(p>0.05)$ difference although control cream cheese was more yellowish in colour than reduced fat cream cheese. It was also observed that overall acceptability of RFCC with $4 \%$ inulin was more than that of made with $6 \%$ inulin but the difference was non-significant $(p>0.05)$ between two inulin levels added cheeses. Overall acceptability of control and RFCC with $4 \%$ inulin was significantly $(\mathrm{p}<0.05)$ higher than that of RFCC. This implies that removal of fat from the product causes significant $(p<0.05)$ influence on the sensory attributes. Incorporation of inulin in reduced fat cream cheese was found to increase flavour, body and texture score. This may due to sweeter taste of the product and masking of acidic flavour but higher level of inulin (6\%) produced too smooth texture of the product, as inulin has been reported as texture modifier (Karimi et al. 2015).

\section{Effect on textural properties}

Reduction of fat increased the firmness of the cheese (Fig 3A). Reduced fat cream cheese was firmer, gummier and chewier than the full-fat control cheese due to its low fat and high protein contents. Firmness was observed to decrease (Fig 3A) with the increased levels of inulin in cheese but did not differ significantly ( $p>0.05$ ) among the cheeses. As fat content decreases, the protein matrix becomes more compact and the cheese texture turn chewier. As level of inulin increased in low fat cheeses the spreadability of cheese also increased (Fig.3B) while index of viscosity (Fig. 3C) decreased but both increase and decrease were nonsignificant ( $p>0.05$ ). Inulin is mainly used as fat replacer because in the presence of water, they are able to form a particulate gel, 


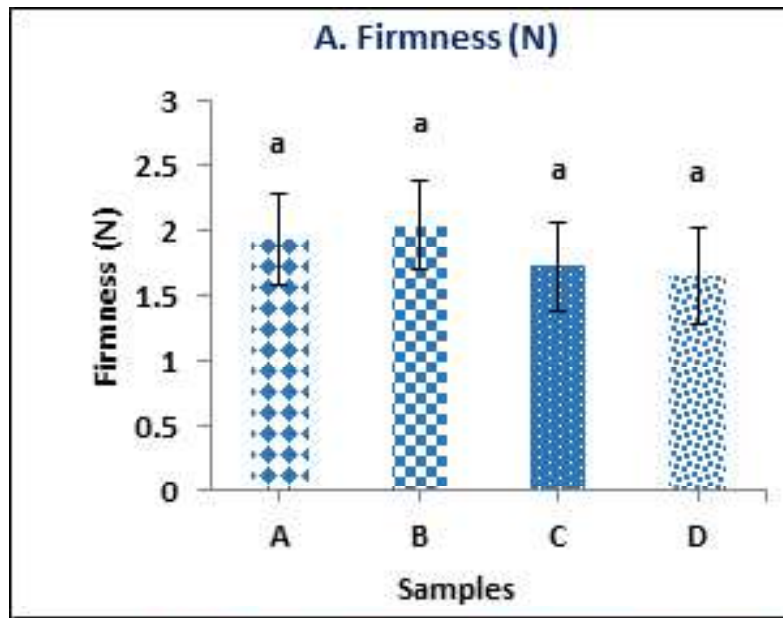

A. Centrol B. RFCC C. RFCC-4\% INU D.RFCC- $6 \%$ INU

thus modifying the product texture and giving rise to a fat like mouthfeel (Franck, 2002; Tungland and Meyer, 2002). Inulin as fat replacer is based on its capacity to form microcrystals and interact with each other thereby forming small aggregates which ultimately may agglomerate into a gel network resulted in a smoothness of the product (Hebette et al. 1998).

\section{Effect on physico-chemical properties}

It was observed that moisture content of cheese increased significantly $(p<0.05)$ with reduction in fat content and it further decreased significantly $(\mathrm{p}<0.05)$ with incorporation of inulin (Table 2). This decrease in moisture content may be due to increase in total solids of the cheese. Inulin contain about 2.5$3.0 \%$ when $4-6 \%$ inulin is mixed with RFCC $(77-79 \%)$, total moisture content of mix get reduced. Water retention property of inulin could increase the water available for salvation of protein chains, resulting in a softer, more easily deformed cheese (Creamer and Olson, 1982). Though there was a decrease in acidity and increase in $\mathrm{pH}$, but variations were not significant $(\mathrm{p}>0.05)$. This decrease of acidity and increase in $\mathrm{pH}$ is probably due to reduction of fat content and increase in carbohydrate content

Hence, based on the sensory, textural and physico-chemical properties, the cream cheese prepared with $4 \%$ inulin was adjudged as the best between two levels of inulin addition. Therefore, addition of $4 \%$ inulin for the preparation of reduced fat cream cheese was optimized as an additive.

Optimizations of Whey protein concentrate level for the preparation of reduced fat cream cheese

Effect on sensory attributes

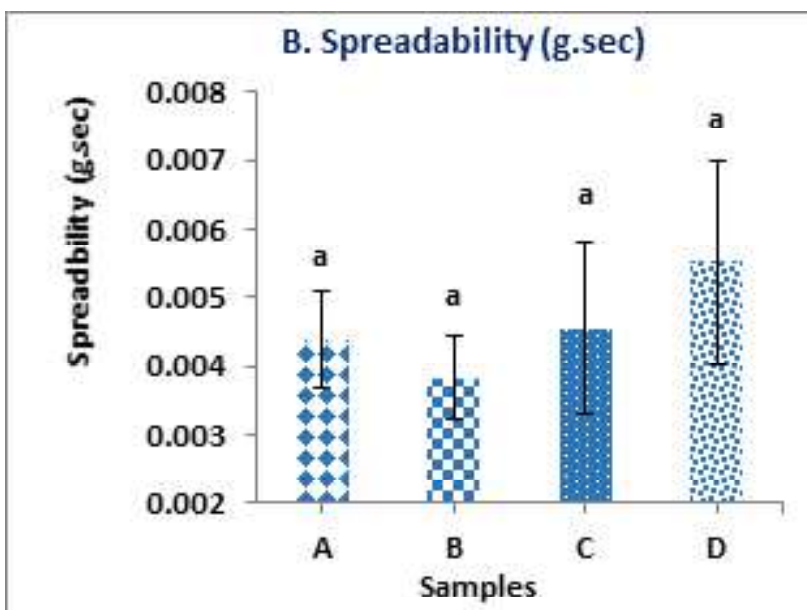

A-Central B-RrCC C-RFCC- $4 \%$ INU D-RFCe- $6 \%$ INU

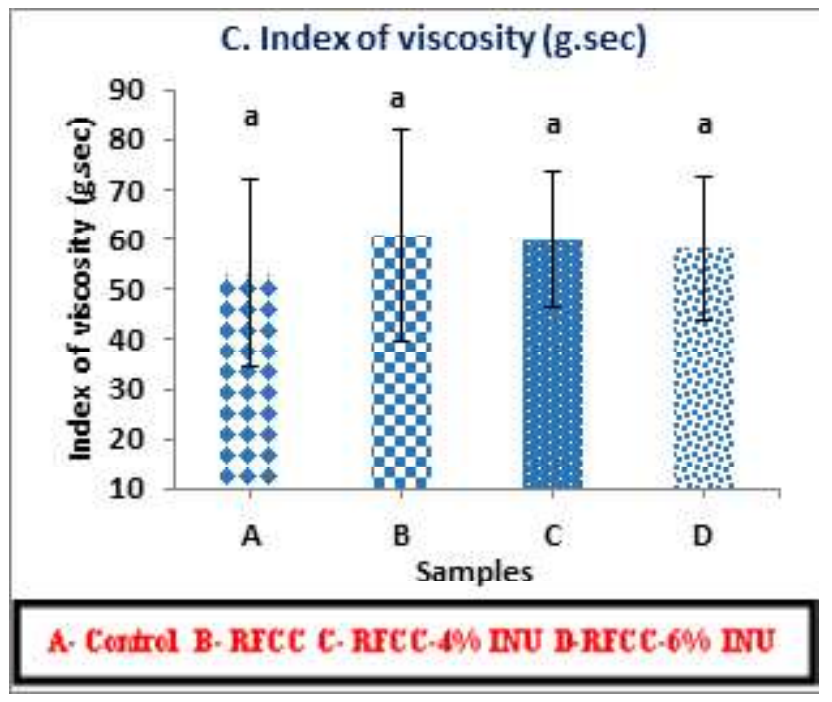

Fig. 3 Effect of inulin incorporation on the textural properties of cream cheese

It was observed that the flavour score of reduced fat cream cheese (RFCC) without WPC was significantly $(\mathrm{p}<0.05)$ lower than control cheese (Table 3 ). The control sample scored maximum of 7.79 followed by 7.55 for $4 \%$ WPC incorporated cheese, 7.26 for RFCC and 7.19 for $6 \%$ WPC incorporated cheese. This implies that reduction of fat causes lack of flavour in the RFCC. However, flavour score of 4\% WPC incorporated RFCC was found almost similar to that of control while significant $(\mathrm{p}<0.05)$ difference was observed between control and RECC with 6\% WPC incorporated cheese. RFCC with $6 \%$ WPC resulted with off flavour and inferior taste which may due to acidic taste and higher amount WPC incorporation. Addition of WPC (4 and 6\%) to RFCC improved the body and texture. Body and Texture of RFCC was significantly $(\mathrm{p}<0.05)$ lower than control and 4\% WPC incorporated RFCC. This may be due to gelling property and high water holding 
property of WPC resulted in improved body and texture. The average colour and appearance scores of the four cheeses did not differ significantly $(\mathrm{p}<0.05)$. The overall acceptability of $4 \%$ WPC incorporated cheese was significantly $(\mathrm{p}<0.05)$ higher than RFCC. It could be noticed that the cheese made with 4\% WPC received scores closer to control cheese.

\section{Effect on textural properties}

It is evident from the Fig 4A that with reduction in fat content, the firmness of cheese increased but addition of 4 and $6 \%$ WPC resulted in lower firmness even lower than control. As level of WPC increased, the spreadability (Fig 4B) increased while index of viscosity (Fig 4C) decreased non-significantly ( $p>0.05)$. The spreadability of $6 \%$ WPC incorporated cheese was highest among control and other experimental cheeses but the differences in spreadability was non-significant $(\mathrm{p}>0.05)$. Multifunctional characteristics of WPC might have provided fat-like attributes due to their major functions like gelling, water binding, emulsification, viscosification and adhesion. Water binding property of whey proteins is important in reduced-fat formulations to retain the increased water in cheese and to replace fat and maintain texture (Jooyndeh, 2009). The results indicated that the replacement of milk fat with WPC in reduced fat cream cheese has an impact on firmness, spreadability and index of viscosity of cheese

\section{Effect on physico-chemical properties}

Addition of WPC showed an influence on acidity and $\mathrm{pH}$ of reduced fat cream cheese. The higher acidities with the more percentages of added WPC could be due to greater buffering capacity (Modler et al. 1983). This may also due to increased availability of nutrients from whey proteins which might have partially influenced the growth of starter bacteria resulting in more lactic acid production in cheese. Based on the sensory, textural and physic-chemical characteristics, the cream cheese prepared with 4\% WPC was adjudged as the best among reduced fat cream cheeses.

\section{Comparisons of quality characteristics between inulin and WPC incorporated reduced fat cream cheeses}

Reduced fat cream cheese with inulin and WPC and control cheese were prepared as outlined in Fig 1. Inulin and WPC of 4\% each and their combinations of $2 \%$ each were added for the preparation of reduced fat cream cheese. The comparision study was conducted separately so results are discuused separately.

Table 2 Effect of inulin incorporation on sensory attributes of of cream cheese

\begin{tabular}{llllr}
\hline Attributes & Control & RFCC & RFCC with WPC & $6 \%$ \\
\cline { 3 - 5 } & & & $4 \%$ & $7.19 \pm 0.37^{\mathrm{a}}$ \\
\hline Flavour and taste & $7.79 \pm 0.30^{\mathrm{b}}$ & $7.26 \pm 0.28^{\mathrm{a}}$ & $7.55 \pm 0.13^{\mathrm{ab}}$ & $7.46 \pm 0.23^{\mathrm{ab}}$ \\
Body and Texture & $7.78 \pm 0.25^{\mathrm{b}}$ & $7.31 \pm 0.16^{\mathrm{a}}$ & $7.83 \pm 0.11^{\mathrm{b}}$ & $7.79 \pm 0.14^{\mathrm{a}}$ \\
Appearance and colour & $7.91 \pm 0.07^{\mathrm{a}}$ & $7.89 \pm 0.12^{\mathrm{a}}$ & $7.95 \pm 0.07^{\mathrm{a}}$ & $7.51 \pm 0.07^{\mathrm{a}}$ \\
Overall acceptability & $7.93 \pm 0.06^{\mathrm{a}}$ & $7.41 \pm 0.09^{\mathrm{b}}$ & $7.85 \pm 0.18^{\mathrm{a}}$ & 7.30 \\
\hline
\end{tabular}

Means with different superscript in a row differ significantly $(p<0.05)(n=3)$

Table 3 Effect of different levels of WPC incorporation on physio-chemical properties of cream cheese

\begin{tabular}{llll}
\hline Samples & \multicolumn{3}{c}{ Parameters } \\
\cline { 2 - 4 } & Moisture (\%) & Acidity & $4.81 \pm 0.23^{\mathrm{a}}$ \\
\hline Control & $72.62 \pm 1.73^{\mathrm{a}}$ & $0.57 \pm 0.07^{\mathrm{a}}$ & $4.76 \pm 0.16^{\mathrm{a}}$ \\
RFCC & $77.23 \pm 0.95^{\mathrm{b}}$ & $0.55 \pm 0.10^{\mathrm{a}}$ & $4.65 \pm 0.34^{\mathrm{a}}$ \\
RFCC-4\% WPC & $74.00 \pm 1.39^{\mathrm{a}}$ & $0.72 \pm 0.09^{\mathrm{b}}$ & $4.58 \pm 0.39^{\mathrm{b}}$ \\
RFCC-6\% WPC & $73.38 \pm 1.50^{\mathrm{a}}$ & $0.73 \pm 0.07^{\mathrm{b}}$ & \\
\hline
\end{tabular}

Means with different superscript in a row differ significantly $(p<0.05)(n=3)$

Table 4 Effect of different levels of WPC on the physico-chemical properties of cream cheese

\begin{tabular}{lllc}
\hline Samples & \multicolumn{3}{c}{ Parameters } \\
\cline { 2 - 4 } & Moisture (\%) & Acidity & $4.58 \pm 0.14^{\mathrm{a}}$ \\
\hline Control & $71.33 \pm 2.50^{\mathrm{a}}$ & $0.67 \pm 0.06^{\mathrm{a}}$ & $4.6 \pm 0.13^{\mathrm{a}}$ \\
RFCC & $77.22 \pm 0.93^{\mathrm{b}}$ & $0.64 \pm 0.09^{\mathrm{a}}$ & $4.64 \pm 0.12^{\mathrm{a}}$ \\
RFCC-4\% INU & $75.59 \pm 1.39^{\mathrm{ab}}$ & $0.61 \pm 0.05^{\mathrm{a}}$ & $4.71 \pm 0.06^{\mathrm{a}}$ \\
RFCC-6\% INU & $73.80 \pm 1.28^{\mathrm{a}}$ & $0.53 \pm 0.03^{\mathrm{a}}$ & \\
\hline
\end{tabular}

Means with different superscript in a column differ significantly $(p<0.05)(n=3)$ 


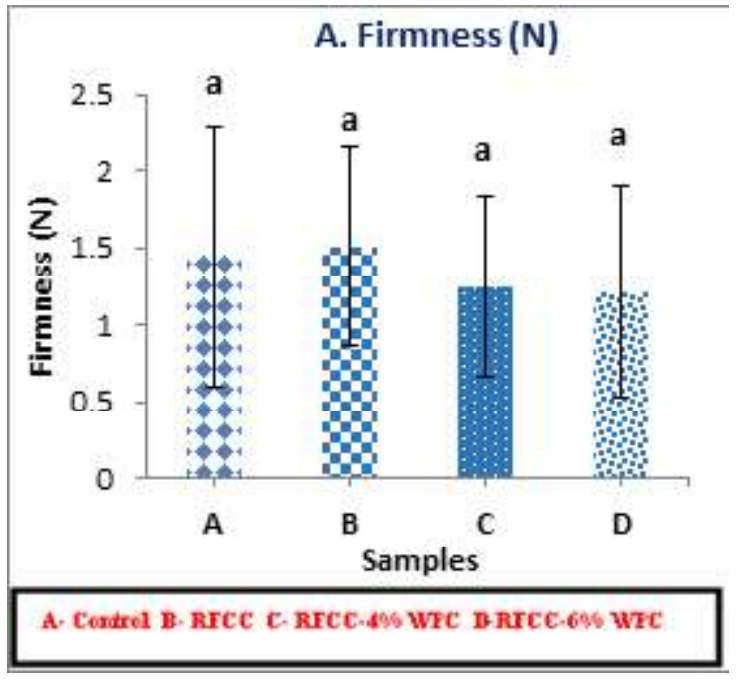

Fig. 4 Effect of different levels of WPC on the textural properties of cream cheese

\section{Effect on sensory parameters}

The effect of inulin and WPC as fat replacers and their combinations on sensory attributes is presented in Table 5. It was observed that the reduced fat cream cheese (RFCC) scored significantly $(p<0.05)$ lower flavour score than control cheese. The control sample scored maximum score of 7.98 followed by 7.91 for $4 \%$ inulin incorporated cheese and 7.55 for RFCC- $4 \%$ WPC and 7.44 for combinations ( $2 \%$ inulin and $2 \%$ WPC). This indicates that removal of fat causes lack of flavour in the RFCC. However, no significant difference $(\mathrm{p}>0.05)$ was observed in flavour between $4 \%$ inulin incorporated RFCC and control cheese. This may due to sweetening effect of inulin which is masking the sourness or acidic taste while RFCC with $4 \% \mathrm{WPC}$ and combination ( $2 \%$ inulin and $2 \%$ WPC) scored significantly lower ( $p>0.05$ ) flavour score than control. This is mainly because of less fat content and more moisture content in cheese. The body and texture scores did not show any significant $(\mathrm{p}>0.05)$ differences among the cheeses except with reduced fat cream cheese. Reduced fat cheese with $4 \%$ inulin scored maximum of 7.83 where it was minimum of 7.42 for RFCC for body and texture. There was no significant $(\mathrm{p}>0.05)$ difference observed in colour and appearance score of both control and experimental cheeses but reduced fat cheese normally appeared to be whiter than full fat cream cheese. The overall acceptability was maximum in control (7.83) whereas it was minimum (7.48) for RFCC. The overall acceptability of $4 \%$ inulin incorporated cheese was almost similar to control. This implies that addition of $4 \%$ inulin could be the most ideal fat replacer to produce good quality reduced fat cream cheese without any adverse effect.

\section{Effect on textural properties}

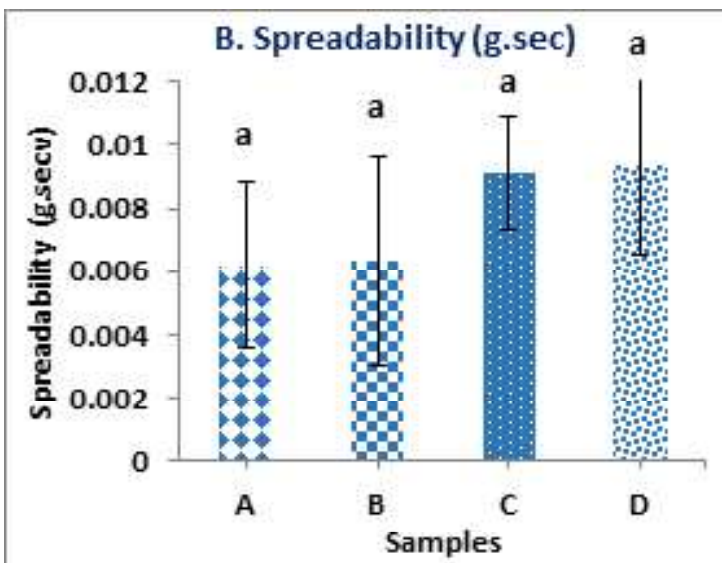

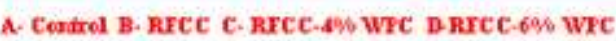

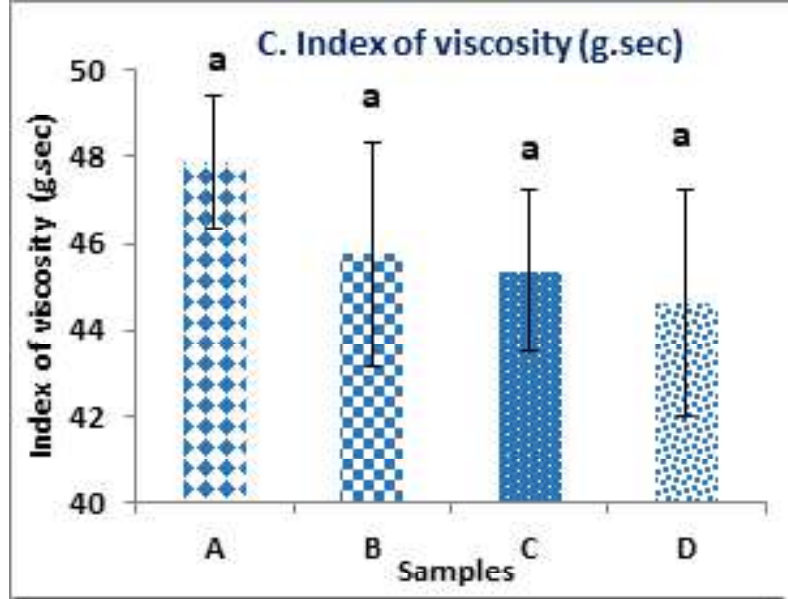

A. Centrel B- RreC C- RreC-4\% Wre D-Rrec-6\% Wre

The changes in textural parameters like firmness, spreadability and index of viscosity of the control and experimental cheeses are shown in Fig 5. The reduced fat cream cheese without fat replacer was significantly $(p<0.05)$ more firm than the RFCC made either with inulin or with WPC or with their combinations (Fig. $5 \mathrm{~A})$. The spreadability of $4 \%$ inulin incorporated chees was significantly $(\mathrm{p}<0.05)$ higher $(0.0167 \mathrm{~g} . \mathrm{sec})$ followed by $0.0159 \mathrm{~g} . \mathrm{sec}$ for combination of $2 \%$ inulin and $2 \% \mathrm{WPC}$ incorporated cheese (Fig. 5B). The lowest spreadability (Fig. 3) of $0.0100 \mathrm{~g} . \mathrm{sec}$ was recorded for RFCC without fat replacers. Index of viscosity (Fig. 5C) of 4\% inulin incorporated RFCC (68.70 g.sec) was significantly $(p<0.05)$ higher than other three variants reduced fat cream cheeses whereas it was non-significant $(p>0.05)$ to that of control cheese (74.13 g.sec). The textural properties of inulin incorporated cheese were almost similar to that of control. Inulin plays the role of lubricant to provide smoothness and a softer texture (Dinkci et al. 2011) which showed maximum spreadability in reduced fat cream cheese among other variants. As the fat content of cheese decreased, firmness and chewiness increased. On the other hand, the addition of inulin modified the texture 
Table 5 Comparison of sensory attributes between inulin and WPC incorporated reduced fat cream cheeses

\begin{tabular}{lccccc}
\hline Attributes & Control & \multicolumn{3}{c}{ Experimental } \\
\cline { 3 - 6 } & & RFCC & RFCC-4\% INULIN & RFCC-4\% WPC & $\begin{array}{c}\text { RFCC-2\% } \\
\text { inulin \& 2\% } \\
\text { WPC }\end{array}$ \\
\hline Flavour and taste & $7.98 \pm 0.39^{\mathrm{b}}$ & $7.45 \pm 0.18^{\mathrm{a}}$ & $7.91 \pm 0.17^{\mathrm{b}}$ & $7.54 \pm 0.09^{\mathrm{ab}}$ & $7.44 \pm 0.17^{\mathrm{a}}$ \\
Body and Texture & $7.73 \pm 0.14^{\mathrm{b}}$ & $7.42 \pm 0.18^{\mathrm{a}}$ & $7.83 \pm 0.29^{\mathrm{b}}$ & $7.66 \pm 0.22^{\mathrm{ab}}$ & $7.67 \pm 1.13^{\mathrm{b}}$ \\
$\begin{array}{l}\text { Appearance and } \\
\text { colour }\end{array}$ & $7.94 \pm 0.06^{\mathrm{a}}$ & $7.81 \pm 0.19^{\mathrm{a}}$ & $7.91 \pm 0.10^{\mathrm{a}}$ & $7.79 \pm 0.21^{\mathrm{a}}$ & $7.95 \pm 0.36^{\mathrm{a}}$ \\
$\begin{array}{l}\text { Overall } \\
\text { acceptability }\end{array}$ & $7.83 \pm 0.24^{\mathrm{b}}$ & $7.48 \pm 0.08^{\mathrm{a}}$ & $7.75 \pm 0.06^{\mathrm{b}}$ & $7.53 \pm 0.10^{\mathrm{a}}$ & $7.65 \pm 0.67^{\mathrm{ab}}$ \\
\hline
\end{tabular}

Means with different superscript in a rows differ significantly $(p<0.05)(n=3)$

Table 6 Proximate composition of inulin and WPC incorporated reduced fat cream

\begin{tabular}{|c|c|c|c|c|c|}
\hline \multirow{3}{*}{$\begin{array}{l}\text { Physico-chemical } \\
\text { parameters }\end{array}$} & \multirow[t]{3}{*}{ Control } & \multicolumn{3}{|c|}{ Experimental } & \multirow{3}{*}{$\begin{array}{c}\text { RFCC- } 2 \% \\
\text { inulin \& } 2 \% \text { WPC }\end{array}$} \\
\hline & & RFCC & RFCC- & RFCC-4\% & \\
\hline & & & $4 \%$ Inulin & WPC & \\
\hline$\overline{\mathrm{TS}(\%)}$ & $29.07 \pm 2.06^{b}$ & $22.0 \pm 0.90^{\mathrm{a}}$ & $24.80 \pm 2.98^{\mathrm{a}}$ & $23.9 \pm 1.30^{\mathrm{a}}$ & $24.53 \pm 1.34^{\mathrm{a}}$ \\
\hline Protein $(\%)$ & $9.65 \pm 0.64^{\mathrm{a}}$ & $11.37 \pm 1.01^{\mathrm{ab}}$ & $10.24 \pm 0.44^{\mathrm{ab}}$ & $12.19 \pm 1.17^{\mathrm{b}}$ & $10.54 \pm 1.39^{\mathrm{ab}}$ \\
\hline Ash (\%) & $0.77 \pm 0.11^{\mathrm{a}}$ & $1.13 \pm 0.21^{\mathrm{b}}$ & $1.73 \pm 0.16^{\mathrm{b}}$ & $1.42 \pm 0.18^{b}$ & $1.59 \pm 0.24^{b}$ \\
\hline
\end{tabular}

Means with different superscript in a rows differ significantly $(p<0.05)(n=3)$

Fig. 5 Comparison of textural properties between inulin and WPC incorporated reduced fat cream cheeses

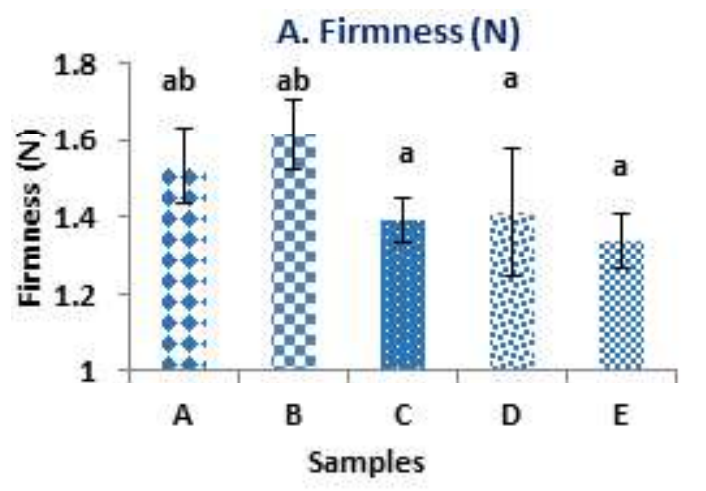

A-Control B-RFCC C-RFCC-4\% INU D-RFCC$4 \%$ WPC E-RFCC- $2 \%$ INU and $2 \%$ WPC characteristics of reduced-fat cheeses, making them more similar to full-fat cheeses, with lower hardness and chewiness than reduced-fat cheeses (Juan et al. 2013). Use of 4\% inulin in reduced fat cream cheese as fat replacer is in agreement with the
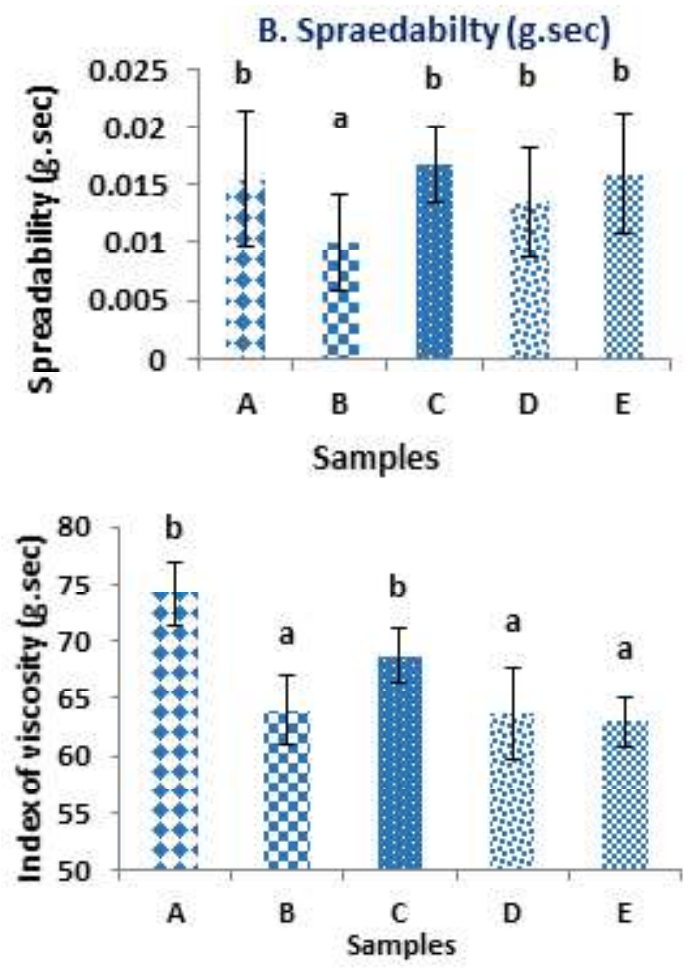

observation of Hennelly et al. (2006) where $3.44 \%$ inulin was used to replace up to $63 \%$ of the fat in imitation cheese. 
The results indicated that the replacement of milk fat with inulin or WPC or in combination in cream cheese affects the firmness, spreadability and index of viscosity of cheeses.

\section{Effect on physico-chemical parameters}

The mean physico-chemical characteristics of control and reduced fat cheese samples are presented in Table 6 . Total solids and fat contents of four reduced fat cheeses were significantly $(p<0.05)$ lower than control cheese because of the reduction of fat where moisture might have compensated fat. Protein content was significantly $(p<0.05)$ higher in WPC incorporated samples due to the presence of WPC in cheese as fat replacer. Ash contents in all the reduced fat cream cheese were significantly $(\mathrm{p}<0.05)$ higher than control whereas no significant $(\mathrm{p}>0.05)$ differences were observed in $\mathrm{pH}$ and acidity among the cheeses

Based on the sensory, textural and physico-chemical characteristics, incorporation of $4 \%$ inulin in reduced fat cheese was found most acceptable in terms of flavour, spreadability and mouthfeel. Hence, the cream cheese prepared with $4 \%$ inulin was selected as the best among different levels of fat replacers for the production of low fat cream cheese.

\section{Conclusions}

This study showed that reduced fat cream cheese with addition of $4 \%$ inulin as a suitable fat replacer will not only provide health benefits like addition of soluble dietary fibre, stimulation of microorganisms in gastrointestinal tract but also may reduce the risk of occurrence of coronary heart disease, stroke, hypertension, diabetes, obesity and certain gastrointestinal diseases without any adverse effect on the sensory, textural and physicochemical properties. The developed reduced fat cream cheese also can be used as a good substitute for butter.

\section{References}

Akýn MB, Akýn MS, Kirmaci Z (2007) Effects of inulin and sugar levels on the viability of yogurt and probiotic bacteria and the physical and sensory characteristics in probiotic ice-cream. Food Chem 104:93-99

Amerine MA, Panngborn RM, Roessler EB (1965) Principles of Sensory Evaluation of Foods, Academic Press, New york.

AOAC (2005) Official methods of analysis of AOAC international $18^{\text {th }}$ Edition. Washington D.C.

Awad S, Hassan AN, Muthukumarappan K (2005) Application of exopolysaccharide-producing cultures in reduced-fat Cheddar cheese: Texture and melting properties. J Dairy Sci 88:4204-4213.

Banks JM, Brechany EY, Christie WW (1989) The production of low fat cheddar type cheese. Int J Dairy Technol 42:6-9

Creamer LK, Olson NF (1982) Rheological evaluation of maturing Cheddar cheese. J Food Sci 47:631-636

Dickinson E (1997) Properties of emulsions stabilized with milk proteins: overview of some recent developments. J Dairy Sci 80:2607-2619

Drake MA, Boylston TD, Swanson BG (1996) Fat Mimetics in Low Fat Cheddar Cheese. J Food Sci 61:1267-1271
Franck A (2002) Technological functionality of inulin and oligofructose. Br J Nutr 87:S287-S291.

Guinee TP, Pudja PD, Farkye NY (1993) Fresh acid-curd cheese varieties. In "Cheese: chemistry, physics and microbiology", pub. by Springer US, pp. 363-419.

Hebette CLM, Delcour JA, Koch MH, Booten K, Kleppinger R, Mischenko N, Reynaers H (1998) Complex melting of semi - crystalline chicory (Cichorium intybus L.) root inulin. Carbohydr Res 310:65-75

Hennelly PJ, Dunne PG, O'sullivan M, O'riordan ED (2006) Textural, rheological and microstructural properties of imitation cheese containing inulin. J Food Eng. 75:388-395

IS: SP: 18. (1981) ISI Handbook of Food Analysis. Part - XI: Dairy Products. Indian Standards Institution, New Delhi

Ibrahim F, Ruvio S, Granlund L, Salminen S, Viitanen M, Ouwehand AC (2010) Probiotics and immunosenescence: cheese as a carrier. FEMS Immunol Med Microbiol 59:53-59

Jooyandeh H (2009) Effect of fermented whey protein concentrate on texture of Iranian white cheese. J Texture Stud 40:497-510

Karimi R, Azizi MH, Ghasemlou M, Vaziri M (2015) Application of inulin in cheese as prebiotic, fat replacer and texturizer: A review. Carbohydr Polym 119:85-100

Katsiari MC, Voutsinas LP, Kondyli E (2002) Improvement of sensory quality of low-fat Kefalograviera-type cheese with commercial adjunct cultures. Int Dairy J 12:757-764

Koca, Metin M (2004) Textural, melting and sensory properties of lowfat fresh kashar cheeses produced by using fat replacers. Int Dairy J 14:365-373

Kruse HP, Kleessen B, Blaut M (1999) Effects of inulin on faecal bifidobacteria in human subjects. Br J Nutr 82:375-382

Lizarraga MS, Vicin DDP, Gonzalez R, Rubiolo A, Santiago LG (2006) Rheological behaviour of whey protein concentrate and $\lambda$ carrageenan aqueous mixtures. Food Hydrocolloids 20:740-748

Lawrence RC, Creamer LK, Gilles J(1987)Texture development during cheese ripening. J Dairy Sci 70:1748-1760

Mattes R (1998) Position of the American Dietetic Assn.: Fat replacers. J. Am. Diet. Assoc., 98:463-468

Miocinovic J, Puđa P, Radulović Z, Pavlović V, Miloradović Z, Radovanović M, Paunović D (2011) Development of low fat UF cheese technology. Mljekarstvo 61:33

Modler HW, Larmond ME, Lin CS, Froehlich D, Emmons DB (1983) Physical and Sensory Properties of Yogurt Stabilized with Milk Proteins1, 2. J Dairy Sci 66:422-429

Phadungath C (2005) Cream cheese products: A review. Songklanakarin J Sci Technol 27: 191-199

Rowland IR, Rumney CJ, Coutts JT, Lievense LC (1998) Effect of Bifidobacterium longum and inulin on gut bacterial metabolism and carcinogen-induced aberrant crypt foci in rats. Carcinogenesis 19:281-285

Sandrou DK, Arvantoyannis IS (2000) Low fat/calorie foods: Current state and perspectives. Crit Rev Food Sci Nutr 40:427-447

Staffolo MD, Bertola N, Martino M (2004) Influence of dietary fiber addition on sensory and rheological properties of yogurt. Int Dairy J 14:263-268

Tungland BC, Meyer D (2002) Nondigestible oligo and polysaccharides (Dietary Fiber): their physiology and role in human health and food. Compr Rev Food Sci Food Saf 1:90-109

Tunick MH, Malin EL, Smith PW, Shieh JJ, Sullivan BC, Mackey KL, Holsinger VH (1993) Proteolysis and Rheology of Low Fat and Full Fat Mozzarella Cheeses Prepared from Homogenized Milk. J Dairy Sci 76:3621-3628

Vidigal MCTR, Minim VPR, Ramos AM, Ceresino EB, Diniz MDMS, Camilloto GP, Minim LA (2012) Effect of whey protein concentrate on texture of fat-free desserts: sensory and instrumental measurements. Food Sci Technol 32:412-418 